\title{
Guarding the Sons of Empire: Military-State-Society Relations in Water, Sanitation and Health Programs of mid-19th-Century India
}

\author{
Sarah J. Halvorson ${ }^{1}$ and James L. Wescoat Jr. ${ }^{2, *}$ \\ 1 Department of Geography, University of Montana, Missoula, MT 59812, USA; sarah.halvorson@mso.umt.edu \\ 2 School of Architecture and Planning, Massachusetts Institute of Technology, Cambridge, MA 02139, USA \\ * Correspondence: wescoat@mit.edu; Tel.: +1-617-253-0567
}

Received: 29 December 2019; Accepted: 3 February 2020; Published: 5 February 2020

\begin{abstract}
Drinking water supply and sanitation have had a strong association with military institutions in South Asia from the colonial period to the present. This paper shows how military-state-society relationships created spaces of differential water access and sanitation burdens in mid-19th-century cantonments in ways that involved complex gender relations. In comparison with previous research, we argue that privileged military enclaves were segregated but never fully separated from larger urban water and sanitation systems. We use historical geographic methods to review the evolving role of military sanitation regulations in cantonments from late-18th-century policies of the East India Company (EIC) through mid-19th-century rule by the British Crown, during which time military cantonments, regulations, and formal monitoring reports were established. Close reading of the British Army Medical Department's Statistical, Sanitary, and Medical Reports (Sanitary Reports) in the 1860s then shows how military-state-society relations diverged from civilian public health programs in ways that persist to some extent to the present day. Health advisors, some of them women, pursued an ideology and tactics to "guard the sons of empire", from what they perceived to be a disease-filled landscape of "lurking evils", "choleric attacks", and "native offensives". We conclude with a discussion of both continuities and change in the relationships between military and civilian public health reforms beyond the barracks.
\end{abstract}

Keywords: cantonments; gender; hygiene; India; military sanitation; water; waterborne disease

\section{Introduction}

Metropolitan regions in modern South Asia have extensive cantonments, military quarters, and defense-related housing estates that have relatively high levels of water and sanitation services compared to surrounding urban neighborhoods. Conditions vary within these defense establishments, to be sure, especially those that have lower ranking soldiers, remote locations, or lower military status. Overall, however, defense-related establishments have competed successfully with public health and civil society institutions for safe water supply and sanitation. This paper examines how safe water and sanitation came to be regarded as paramount needs of the defense establishment in ways that embodied the privileged status of military people and places, along with their semi-autonomous administrative control, financing, and managerial culture.

The historiography of colonial sanitation and empire in India is extensive. During the colonial period, for example, the Army Medical Department's Statistical, Sanitary, and Medical Reports (Sanitary Reports) listed prominent works on Health in the Tropics by Mr. Moore of the Bombay, Baron Larey's brochure on the Construction and Hygiene of Hospitals, and pamphlets such as Dr. Milroy's On the Health of the Royal Navy, to name a few. Post-colonial water, sanitation, and hygiene research continues to 
underscore the colonial origins of contemporary sanitation politics and problems [1] (pp. 2-3). While the critique of privileged colonial and postcolonial military enclaves generally holds up, we show that it has had a dynamic relationship with civilian sanitation movements, social relations, and urban settlements. We begin with a brief account of how military sanitation programs and policies developed from the late-18th century to the mid-19th century. Following the 1857 revolt and transfer of rule from the East India Company (EIC) to the British Crown, military and civilian sanitation policies separated in ways that continued even after the independence of India and Pakistan in 1947, as plots within cantonments and defense housing societies became increasingly available to elite civilian buyers $[2,3]$.

Historical geographic methods are used to understand these water and sanitation programs in defense-related spaces of South Asian cities. They shed light on the separate and unequal character of military water and sanitation services. Establishment of colonial cantonments starting with Barrackpore in Bengal, north of Calcutta, in $1765 \mathrm{CE}$ introduced the design of separate waterworks and sanitation facilities, coupled with the formal spatial layout and regulation of cantonments [4]. Military water and sanitation systems were purposely separated from those of nearby settlements. Even so, cantonments had water and sanitation problems, as well as dynamic socio-spatial relations that challenge the critique of them as strict enclaves.

We go on to show how the path to separate and superior military water systems was triggered by high soldier mortality rates in war and peace. The trajectory of change was not self-evident, uniform, or confined to military enclave spaces. From the late-18th century onwards, military, civilian and traditional sanitation movements developed in dialogue, collaboration, and competition with one another. A pivotal shift in policies and institutions occurred after the 1857 rebellion, which had high disease related mortality. Massive troop losses from infectious diseases led to increasingly segregated policies and practices by gender, class, caste, and rank. Military water and sanitation in India developed within a global context, with parallel military sanitation movements in the U.K., U.S., Europe, and elsewhere.

From what would a British soldier, the supposed guarantor of imperial hegemony in colonial India, need to be "guarded"? What were the foremost threats to his person? In mid-19th century India, British soldiers were perceived by the colonial regime to be under attack. In addition to "unruly tribals" and the largest rebellion the British had faced in 1857, there was a perceived siege that was even more ominous, uncontrollable, and daunting. Disease was a terrific threat to the health and welfare of British soldiers. The high incidence of death in the 1850s to 1860s (an average of 69 deaths out of every 1000 British soldiers annually) struck fear and concern throughout the colonial administration [5]. Ravaging cholera epidemics of the period weakened the state of the troops, compromised the power and prestige of the British Raj, and aroused public outcry in Britain over the lack of care and attention to the well-being of the sons of the empire.

In response, the Army Medical Department, in alignment with the 1859 Royal Commission to Enquire into the Sanitary State of the Army in India, committed itself to investigating the army's health and sanitation condition in annual Statistical, Sanitary, and Medical Reports. A parallel set of public Sanitation Commissions was established in the three Presidencies of Calcutta, Bombay and Madras to monitor and advise on broader public water, sanitation, and health concerns.

In addition to the 1857 rebellion and the geopolitical shift from Company to Crown, military water and sanitation became gendered in new ways during the mid-19th century. The legendary Florence Nightingale [6,7] was involved in the 1859 Royal Commission report. She built upon her military nursing and sanitation work in the Crimean war (1854-1856) through a combination of passionate advocacy for the British soldiers in India, insisting upon a solid empirical basis for policy. She also argued for expanded consideration of community health and sanitation beyond the barracks over the last four decades of the 19th century.

Nightingale was one of many women committed to addressing water and sanitation problems and programs of mid-19th century settlements in India [8,9]. Military and public sanitation officers, men and women, Indian and British, were engaged in intense dialogue and debates with one another. 
These debates concerned the relative merits of surface and ground water, traditional and western medicine, spatial segregation and behavior regulation. They also involved scientific debates ranging from filter and pump designs to perceived water quality differences between surface water and well water and competing theories about pathways of cholera contagion.

Our approach complicates the modern critique of military sanitation as enclaves while acknowledging the divergence of military and civilian water and sanitation policies in decades following the 1857 rebellion $[4,10,11]$. It sheds light on the complexity of socio-spatial water relationships among bazaars, villages, waterways, and cities adjacent to military enclaves. This interpretation is based on a close reading of the Army Medical Department (AMD) annual Statistical, Sanitary, and Medical Reports (referred to here as Sanitary Reports) for the period from 1860 to 1872, which brackets major policy documents like the Royal Commission report of 1863 and Cantonment Act of 1864 [12-22] (Figure 1).

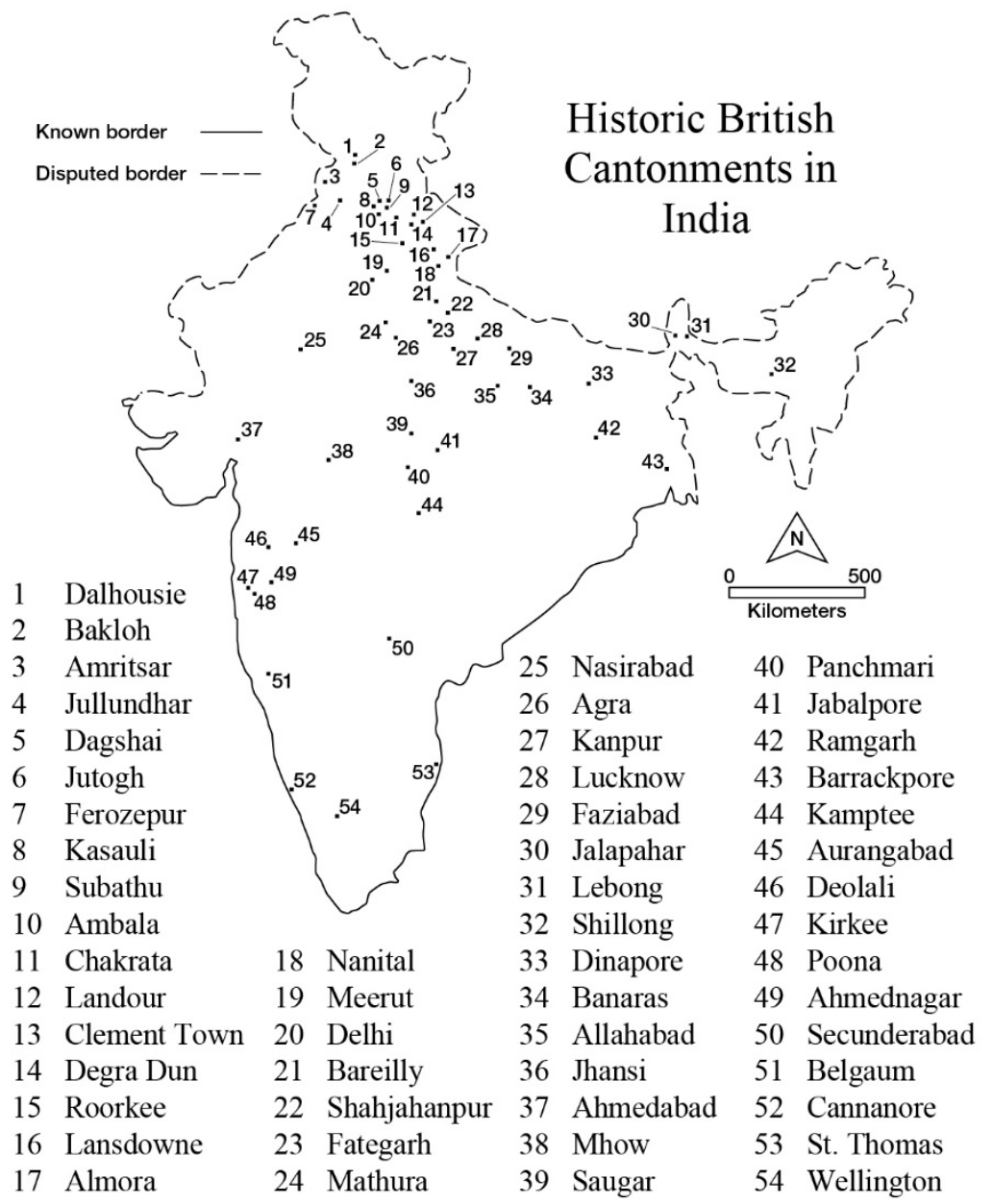

Figure 1. Map of Historic British Cantonments in India, c. 1864, after Kalal [23] (p. 28b) and Kulkarni [24] (216) by Miles Scheuering, University of Montana, USA.

Following a brief discussion of methods, this paper is structured in three substantive sections: (1) antecedents of military sanitation in late 18th- and early 19th century India; (2) major themes in the Sanitary Reports of the Army Medical Department; (3) and discussion of changing ideologies and tactics in military and civilian water and sanitation programs in India. An important thread that runs throughout the paper involves the gendered logic of waterborne disease requiring sanitary reform. By the mid-19th century, theories of safe water supply, drainage, sanitation, and public health systems were linked with expressions of wider 19th century ideologies and debates about gender, class, and racial separation that have persisted to varying degrees to the present day. Indeed, recent scholarship 
demonstrates how gender and state practices currently within India's water and development sectors reflect rippling effects of these colonial issues [25-27].

The imperial project had a sanitizing logic that emerged in the 1860s from the view of Indian settlements as filthy, impure, and unhygienic places, on the one hand, and of British troops as susceptible and even prone to impurity, pollution, and disease in the context of war, on the other. This duality of disease was closely associated with changing theories about climate, water, race, and soldiers themselves. Gender was likewise closely associated with pure and impure places, people, sites, and environments. Military water and sanitary policies continue to influence modern South Asian cantonments and surrounding cities, which calls for a critical assessment of their logic and legacy.

\section{Materials and Methods: Reading Army Medical Department Sanitary Reports}

For purposes of the army, the "science of empire" systematically described, classified, and catalogued elements of India that had a bearing on the health of the British soldiers. This included perceived relationships between diseases and climate, topography, vegetation, soils, social interactions, drainage systems, and troop movements, all of which were discussed in the AMD Sanitary Reports. The value of intimately knowing "an alien world of 'communities' and 'cultures,'" was fundamental to the survival of colonial rule in India [28] (p. 1128).

The first step in this process was to briefly trace out the antecedents of formal military cantonments, drawing upon documents that guided their development, siting and layout to secure safe water supplies and sanitation. This step yields a narrative of cantonment development policies in the late 18th through early 19th centuries.

The second and main method employed in this paper involved a close reading of the Sanitary Reports from 1864 to 1869 . Those reports shed light on the processes by which army medical officers compiled and commented on health hazards. Sanitary Report sub-sections address broad subjects like "On the Health of the Troops Serving in India," "The Home Quarters of the Army," and "Review of the Progress of Hygiene." Special subjects included, "Typhoid Fever in India from a Sanitary Point of View," "Special Sanitary and Topographical Report on Kurrachee," "Instructions for Conducting an Enquiry into Cholera in India," and "The Value of Taste as a Measure of Quantity in Solutions of Different Alkaline and Earthly Salts in Drinking Water". Each Sanitary Report began with a statistical record of five classes of sickness and mortality (Table 1).

Table 1. Classification of illnesses in the Army Medical Department Sanitary Reports.

\begin{tabular}{cl}
\hline Class Categories & \multicolumn{1}{c}{ Description } \\
\hline Class I & $\begin{array}{l}\text { Miasmatic diseases (eruptive fevers, dysentery and diarrhea, spasmodic cholera, sore } \\
\text { throat/Tonsillitis and influenza, ophthalmia, rheumatism), enthetic, dietic, parasitic }\end{array}$ \\
\hline Class II & Diathetic diseases, tubercular \\
\hline Class III & $\begin{array}{l}\text { Nervous system, circulatory, respiratory, digestive, urinary, reproductive, locomotive, } \\
\text { integumentary }\end{array}$ \\
\hline Class IV & Diseases of Nutrition \\
\hline Class V & Accidents, battle, suicide, execution, corporal punishment \\
\hline
\end{tabular}

Cholera was a special scourge during this period. It was the hope that AMD, "investigations, together with chemical analysis incidental to them, will solve many of the disputed practical points in the epidemiology of cholera, and enable measures of prevention to be taken against the disease, with better hope of success than heretofore" [20] (p. 191). On the one hand, the AMD methods continued Nightingale's systematic empirical approach to sanitary reform, but on the other hand, they excluded the female subject and did not include statistical data on women and children in military stations until the 1920s. 
The Sanitary Reports presented geographical statistics for India in the wider imperial context, enabling comparison by geographic area, disease type, and affected subgroups. A uniform statistical method was followed. For example, Figure 2 indicates an unusually high disease incidence in 1869 in Bengal Presidency compared with Bombay and Madras in the preceding eight years, which was a common pattern but unusual for its magnitude. Detailed tables and appendices provide a breakdown of morbidity and mortality for diseases in all classes in all cantonments.

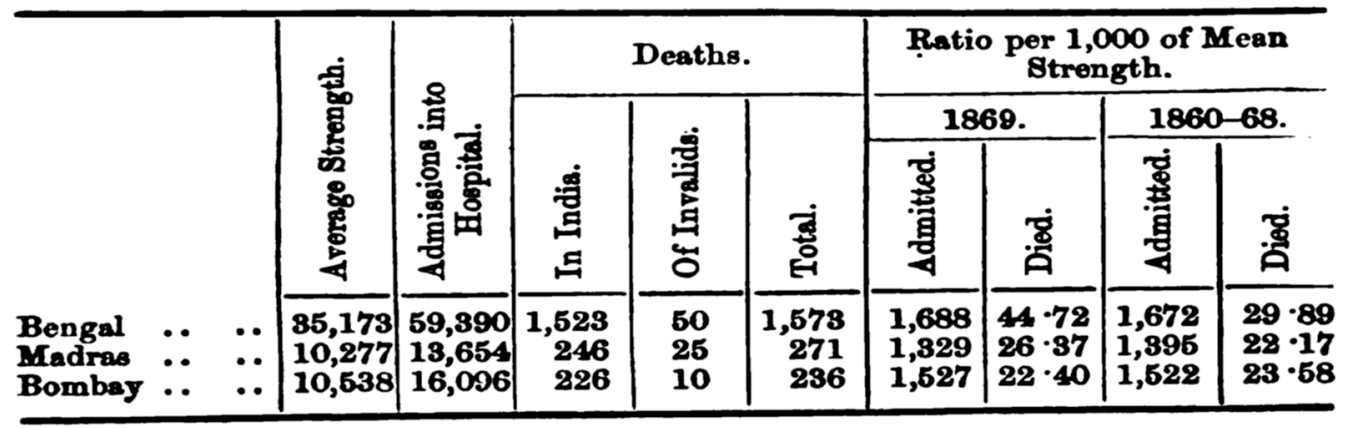

Figure 2. Disease incidence by Presidency in 1869. Source: [22] (p. 157).

These quantitative analyses provided the British army with an often-disconcerting view of how many men were dying and from which epidemics and diseases. It underscored the need for seeking the root causes of ill-health and identifying ways to safeguard men in the barracks. The aim of reading the Sanitary Reports was to discern the perceived sites and sources of impurity. Investigators adopted surveillance techniques, scientific methods, keen observation skills and imaginative imagery that led to striking narratives and speculation about the mysteries of sickness.

\section{Antecedents and Advent of Military Sanitation Reports}

Medicine has ancient associations with military regimes in India, and globally, as armies have high rates of injury, wounds, and infections [29,30]. Pre-colonial European travelers to India who had medical training, like Francois Bernier (d. 1688 CE), gained access to the Mughal imperial court for their medical advice and treatment. Research on pre-colonial medicine underscores the Hippocratic-Galenic-Avicennian foundation of airs, waters, and places, albeit with few detailed studies of the healthiness of specific military places [31,32]. The Mughal empire had massive armies and encampments, which had large water and sanitation requirements, but they also tended to have temporary modes of deployment and settlement between military campaigns. Research on pre-colonial waterworks has focused more on impressive forts, palaces, and gardens than on conditions in encampments and settlements [33].

The East India Company's military success at Seringapatnam in 1757 CE led to an increase in the number and training of surgeons in the Bengal Medical Service and Indian assistants in the Subordinate Medical Service created in the early 1760s CE [34]. The first cantonment was appropriately named Barrackpore, established in 1765 CE some twenty kilometers north of Calcutta. It lay well beyond the city limits, sited there for strategic vis-à-vis sanitation purposes. Early army regulations published in 1798 noted requirements for cleanliness in camps and hospitals and for "wholesome water" [35]. By the end of the 18th century, the profession of "doctory" developed alongside traditional practices of vaidyas and hakims, and a new urban hospital in Calcutta in $1835 \mathrm{CE}$, followed by related developments in other provinces [36]. Disease became a flashpoint when a mutiny took place at Barrackpore in 1824 during a cholera pandemic. To better comprehend and control disease the field of "medical topography" developed in the 1820s to evaluate and map locally healthy and unhealthy places, the latter being characterized by poor drainage and perceived miasma $[37,38]$. Medical topographies thus paid special attention to water bodies and water quality [39]. The Government of India Charter Act of 1833 (also known as the St. Helena Act) increased the East India Company's administrative 
and military authority while reducing its trading authority, which further expanded its emphasis on cantonment development [40]. John Snow's epidemiological discovery of the waterborne route for cholera transmission in London in 1854 did not reach sanitarians in India in a major way until a decade later.

The British Army Medical Department began publishing its Statistical, Sanitary, and Medical Reports in 1859. These Sanitary Reports compiled observations on the epidemiology and sanitary conditions of barracks, cantonments, and surrounding landscapes. Possessing no executive power, however, the Army Medical Department fulfilled an advisory role for the British colonial regime on interventions that could improve the physical and mental condition of the troops [41]. In addition to the attention given to troops in India, the Sanitary Reports surveyed the health of the troops positioned in China, West Indies, Africa, Australia and other distant military posts. India featured prominently due to its geographic scale within the empire.

The most significant event influencing imperial health policy in this period was the Indian troop rebellion in 1857. Until this event, British administration was executed by the East India Company. The East India Company adopted a number of policies that disrupted cultural traditions of Indian social groups. Some of these policies (e.g., banning sati (widow immolation)) were clearly progressive, while others involving tariffs and taxation wrought hardships, conflict, environmental degradation, and famine. The final straw fueling Indian troop resentment to British authority was reportedly a technique for loading rifles that entailed greasing cartridges with animal fat. Convinced that the change in rifle loading was a plot to violate religious norms and promote Christianity, the Indian troops rebelled.

The Rebellion involved sieges of British troops, physical attacks on civilians on both sides, including murder of European women and children that struck at colonial constructions of white femininity and racial "Otherness" [42]. Sensational news coverage portrayed these events with images that, "remained fixed in the public mythology of 1857 and were continuously reinforced in late Victorian popular narratives and visual representations as well as in the collective British imperial memory" [42] (p. 291). The East India Company was blamed for neglecting the health and welfare of British troops, which contributed to the transfer of imperial power from the East India Company to the Crown. The number of soldiers who had died from disease far out-numbered losses incurred during combat. The British government also realized that it could not afford the loss of soldier vitality to disease and initiated a systematic investigation of military sanitation and hygiene.

The emergence of military health statistics in India did not exist in isolation from wider processes of imperialism. At about the same time a Royal Commission established troop losses in the Crimean War (1853-1856) and prepared "Notes on Matters Affecting the Health, Efficiency, and Hospital Administration of the British Army" (1857) with the leadership and field experience of Florence Nightingale. The 1857 rebellion one year later prompted a second Royal Commission in which Nightingale initiated a statistical survey of morbidity, mortality, and sanitary conditions at all military stations in India [43].

Many scholars have suggested that the central concern of British health policy at the time was to ensure the health of the army, and then to meet the needs of the European community by upgrading the health and hygiene of Indian cities, towns and villages [24,44]. It was also recognized that interactions between the British colonizers and the Indian colonized population were numerous. Harrison [5] (p. 9) notes that, “Though Europeans inhabited barracks or 'civil lines' usually at some remove from indigenous dwellings, they had frequent contact with Indian servants, and troops moved under few restrictions among the bazaars and the entourage surrounding military cantonments." Significantly, Nightingale did not limit the scope of surveys or her "Observations on the Evidence Contained in the Stational Reports Submitted to Her by the Royal Commission on the Sanitary State of the Army in India" [42] to British troops and barracks. She commented critically on the problematic spatial, social, and environmental relationships between troops and Indian communities, and she maintained an extraordinarily focused personal commitment to analyzing and advocating sanitary and related social 
reforms in British India through the four remaining decades of her career $[6,7,45]$. The enclave critique of military water and sanitation interventions was thus always in dialogue, tension, and competition with civilian public health. For example, the Cantonment Act of 1864 was adopted in the same year as the public Sanitation Commission in Bengal [46]. The Commission gave significant attention to military water and sanitation in its reports, proceedings, and abstracts. The 1864 Act was followed by similar acts for Madras in 1866 and Bombay and Punjab in 1867 [47-49].

Nightingale was not alone. According to Hume [40], civilian Sanitary Commissioners in the three presidencies believed that improving the sanitary condition of the army would depend upon ameliorating sanitary deficiencies in India more generally. These beliefs were in accord with the "miasmic" theory of disease transmission in Europe and the U.S., which associated poorly drained and ventilated environments with infectious diseases [50] The U.S. Sanitary Commission created during the American Civil War in 1861 likewise pursued these broad social and environmental theories and related reforms within a pressing military context [51]. Competing waterborne contagion theories of disease were put forward in international sanitation conferences, the first of which occurred in Constantinople in 1866, with specific concerns about cholera in Bengal, which added trade and travel constraints to military concerns. Cantonments experimented with the regulation of settlements within a 5- to 10-mile radius of cantonments. However, the germ theory of contagion and scientific water quality testing, treatment, and regulation did not gain ground until later in the 19th century [52]. Until that time, relocation of Army cantonments and Government civil lines to higher well-drained areas, away from dense urban centers served sanitary as well as military tactics [53]. These complex social and spatial antecedents contributed to the advent of the AMD Sanitary Reports.

\section{Results}

This section flags four major interpretive themes that stand out from our reading of the AMD Sanitary Reports from 1864 to 1869 . While there is an enormous body of empirical data in these reports, which vary by cantonment and presidency, the critical perspective of this paper focuses on the published interpretations of those empirical patterns.

\subsection{The Landscape of "Lurking Evils" and "Choleric Attacks"}

The Sanitary Reports convey indelible images of "lurking evils" and unpredictable "choleric attacks" that were embedded in the British medical psyche. Cholera became the primary aggressor on the 19th century medical frontier [50]. From descriptions in the Sanitary Reports, cholera was portrayed as a phenomenon rising out of the Bengal landscape to attack soldiers with debilitating intensity across South Asia. According to T. Graham Balfour, the Deputy Inspector-General of Hospitals and Head of the Statistical Branch, the regiments stationed at Meean Meer (Lahore) in 1861 were actually "cut off" from other troops by cholera in a matter of a few weeks and subsequently sustained a very high mortality rate: "This epidemic in one quarter caused upwards of half the deaths which occurred among the European troops during the whole of the year, and was so virulent that two out of every three cases terminated fatally" [14] (p. 116), (see [54] for a detailed exploration).

Inspired by tremendous fear and anxiety associated with cholera, the sanitary investigators sought to explain where its next surprise strikes would come [55]. In his "Sanitary Review", Dr. Beatson [14] (p. 286), Deputy Inspector-General of Madras, felt compelled to note in his report:

Dr. Jephson (King's Dragoon Guards) remarks that cholera is always lurking about the country through which these men marched. I would not quite say this. The old Madras road was in some places always very risky, if not unhealthy; but nearly all the low country is now traversed by rail, and from Tripatore to Bangalore is not considered an unhealthy road. The most unhealthy part is the immediate neighborhood of Tripatore.

In these debates regarding pockets of cholera, the physical features near the troops' stations played an important role as bearers or transporters of sickness. Rivers were described as influential pathways 
of defilement and disease. The hospital in Fort St. George "passes over the filthiest parts of an intensely filthy town; the (wind) reaches the hospital loaded with the impure exhalations from the filthy stagnant backwater called a river, which is scarcely one hundred yards from the hospital. This lagoon is now the cesspool of a large portion of Madras, and is at times overpoweringly disgusting" [14] (p. 287).

These descriptions of towns and rivers as filthy were no doubt accurate, and not unlike contemporary debates about the Thames in London, they first led to strategies of distancing Army quarters from low-drained densely populated areas, and then to extensive drainage and sewerage of large urban areas. At the same time, there was increasing skepticism that these large-scale interventions, including hill towns, were effective in preventing diseases like cholera. That skepticism stopped short of recognizing cholera as a waterborne disease, as advocated forcefully by the Surgeon-Major of Punjab, A.C.C. de Renzy [40,56].

\subsection{Besieged at the "Home Quarters"}

The threat of disease risk in places regarded as "Home Quarters" was palpable. Military surgeons and administrators were distressed by the state of barrack water supplies, drainage systems, waste piles, and negligent cleansing of latrines, urinals, and ablution rooms. Multiple proposals offered suggestions for improving the hygienic state of sanitary affairs at the barracks. For the Royal Regiment the issue of how to provide an ample drainage system was debated in 1861:

An extensive scheme of drainage was proposed by a committee ... it was proposed to connect all the latrines with main drains, and by means of water to flush and carry off everything. The Supreme Government of India very fortunately vetoed any such experiment. In the first place, the question of the amount of water procurable has not been satisfactorily settled... The principle which the Supreme Government wisely insists must be observed in any drainage scheme for Trimulgherry is, that all the content of latrines, of urinals, and all refuse and offal from kitchens and barrack-rooms, must be removed, and the drainage will simply be to carry off surface water, and refuse water from bathrooms and lavatories [14] (p. 293).

The British soldier's "home life" was further destabilized by a large quota of sick cases involving syphilis and its allied affections. The "extensive prevalence of venereal disease" was viewed as causing great "inefficiency among the men" and compromising their abilities to serve the British military [14] (p. 283,308). Mr. Hadaway, the Deputy Inspector-General of Hospitals reporting on Bombay [57] (p. 321) argued,

Steps should be taken for the establishment of hospitals at every native town in the neighbourhood of troops, venereal being a constant and prolific source of numerous admissions amongst them to hospital, as well as an ultimate cause of undermining many constitutions and rendering the men, in consequence, much more liable to the influences of malaria and prevailing epidemics.

Since in England "antagonism upon religious grounds" dissuaded prostitution, the Sanitary Reports sought to re-assure the army administrators that in India it must be "borne in mind that none of these women are ever seduced by Europeans" [15] (p. 302).

The connection with clean water supply may seem tenuous, but clean drinking water was linked with temperance and related moral movements during this period. The need for improving the "moral state" of the British soldier was a comprehensive concern that became focal in the intimate relations between European men and Indian sex workers:

... is it likely that any system of moral training applicable to the various phases of military life would be effectual? ...When women of loose character are forbidden a residence in military cantonments, it is found that no available police force can keep them from coming in at night ... Moreover, soldiers could not be effectually restricted from meeting these women beyond 
the cantonments. Assuming, then, that the prophylaxis of non-association... is not attainable, the question next presents itself of mitigating the evil whilst permitting association [15] (p. 304).

There were various attempts to regulate the location, distance, and types of sexual contact. The preferred "remedy to this evil" passing between the British soldiers and women was the "official supervision of the women" in oppressive "lock hospitals" [15] (p. 301):

The most effectual system, it is generally supposed, would be to allow women to reside in sudder or regimental bazaars, to be registered and kept under careful supervision, and when found diseased to send them for treatment to lock hospitals established for the purpose under European control, and not to permit women of this class to reside in cantonments, unless under these restrictions [15] (p. 304).

According to Lal [44] (p. 32), these concerns about venereal disease in the "Home Quarters" gave rise to the regulation and frequent medical inspection of female prostitutes, known among the British officers as "disreputable women," at military cantonments (cf. [58,59]). This level of surveillance for military purposes was also justified as improving Indian women's health. However, health activists like Nightingale and local army medical officers criticized the punitive treatment of women in lock hospitals, as well as the fivefold greater incidence of venereal disease in British troops compared with native troops [45] (p. 230-232). The connection between purity of behavior and of water supplies was explicit in temperance movements in England at this time, but it had little purchase in the army barracks and surrounding neighborhoods in India.

\subsection{Native Offensives: Bazaars, Villages, Temples, and Sacred Sites}

When assessing potential disease "attacks," the sites emphasized for surveillance of "native offensives" included bazaars, villages, temples, and sacred places. These sites were deemed consistently problematic. Sanitary investigations asserted that the health of soldiers depended upon critical assessment of the social and cultural contexts in which they were immersed. This involved mapping the prevalence of disease in surrounding Indian communities. Health data were used to establish correlations between the when's and where's of attacks, and to explain the circumstances in which some places escaped epidemics while others did not. Careful study of "native spaces" helped explore questions regarding the etiology and diffusion of cholera and other enteric diseases in military spaces.

Local bazaars and villages, especially those in close proximity to the "Home Quarters," were seen as dangerous and offensive especially since "a great number of natives ... recognize no principle of sanitation, and not always even decency, in the localities they select for their matutinal requirements" [15] (p. 284). Some investigators postulated that "exhalations" from the rotting filth in the streets of Indian towns could combine with specific atmospheric conditions to trigger outbreaks of disease. Bazaars and villages were "remarkably objectionable" "sources of reprehension." Consider the critique of Trichinopoly where:

Dr. Scott, Surgeon of the 105th, expresses himself emphatically as to the very objectionable position of the barracks in proximity to the native bazaar, which is fertile in sanitary dangers difficult to be dealt with, and being within close sphere of the troops, large numbers of cattle, he states, are concentrated within a limited area, on which a slaughter-house exists, and the ground around it is saturated with blood, fouled with offal and dung-heaps, public latrines under no conservancy system, and within 200 yards of the barracks, adding to pestiferous complication [15] (p. 277).

The negligence of "natives" to build latrines despite "having facilities for irrigation and drainage for the purpose of tillage, extensive cultivation" seemed nonsensical and illogical: 
It is, nevertheless, the case that the natives of India have little or no idea of the value of sanitary arrangements. It would be difficult to discover, in any land where European civilization has so long been presented to the people, a more complete abnegation of practical sanitary measures. In few conditions have they improved very much; in none probably have they walked hand in hand with us; but amongst all the associations that generate, or assume a stimulus, from civilization, there seem none that have been less influenced than what are understood as the prevenTable sources of disease. It is not that a leaven merely of their old customs still prevails amongst the people; but in the agricultural districts, at all events, the domestic habits of centuries back exist. The calls of nature are obeyed in the immediate vicinity of their villages and houses; no privies nor isolated localities are anywhere found [15] (p. 300).

Not only were bazaars and villages considered "indifferently drained," producing "vile exhalations," and their condition symbolic of lack of a "sanitary mentality," they were also associated with "deleterious native liquor" which provoked cases of diarrhea, and additional complacency among the soldiers. Medical administrators noted that it is easy for the "natives" to produce these "country intoxicating liquors" since the process merely involves converting the sap of local trees into "an intoxicating beverage through the fermentation process." This concern again invites comparison with contemporary drinking water movements that aimed to offset the desire for liquor in England and the colonies [60].

From a medical standpoint the close proximity of bazaars, villages, and "native liquors" to cantonments was dangerous, and proposals were designed to remove some bazaars "to a more distant yet convenient locality" [15] (p. 323). Another suggestion to stave off the threat of illness posed by villages and bazaars was to implement a daily system of statistical analysis to uncover the "laws of progress" of cholera and other diseases among the Indians. In addition to the bazaars and villages, Hindu temples and places of worship were admonished for purported lack of hygiene and purity.

Temples in particular were represented in Sanitary Reports as sources of impure beliefs as well as material conditions. For instance, the Benares temple to Shiva, “... is crowded with emblems of the creative deity Siva; the Linga is everywhere seen. It is a strange sight....a sad condition after Christian occupation for so many years. Greek amongst the heathen mythologies is lascivious enough, but it is purity itself compared with Hindoo mythology" [15] (p. 301). In addition to these "sad" places of worship, the celebrations of Hindus outside of temples are depicted as triggers of disease. For example, Hindu worship and disease were associated in accounts of the 1862 cholera epidemic: "it appears to have originated amidst a great native festival at an ancient Hindoo city about forty-six miles from the Station, and to have thence radiated over the country...." [15] (p. 277). From the British sanitary point of view, Hindu pilgrimage and bathing at places like Hardwar on the Ganga seemed oblivious to the "facts" surrounding the causes of disease:

The rain was accompanied with a considerable fall of temperature, and the pilgrims were drenched, the soil, a loose sand and gravel, and in places marshy, was saturated with water; the sewage must have been washed out of the trenches, and the water of the Ganges and of the wells must have been contaminated. The Hindoos thought that some miasm (sic) followed the rain and spread through the camp, but of this there is no evidence. What is certain is that the water was contaminated both in this way and by the bathing of the pilgrims the following day, and that every person in the camp drank of, as well as bathed in, this contaminated water [20] (p. 256)

Interestingly, this passage distinguishes between the miasmic theory of disease, attributed to Hindus, and waterborne sewage contamination. As noted earlier, these two theories of contagion were often linked as well as debated in mid-19th century justifications of sanitation interventions and policies. 


\subsection{Tactical Responses: Reconnaissance, Troop Movements, and Maneuvers}

The Sanitary Reports indicate that by 1864 when the new Cantonment Act was passed, some advances in the sanitary condition of the British troops were noticeable as a result of the "observance of sanitary rules." Rates of mortality in some locations, e.g., Madras Presidency, actually reduced, but the need for sustained tactical responses was apparent. The Army Medical Department compared the design and location of barracks and camps with the health of troops. Theories of acclimatization put forth by medical personnel were addressed through training programs on the "requirements for living in India, and as a consequence the habits to be avoided" [20] (p. 298).

Another major tactical way to guard the health of soldiers involved army deployments and maneuvers to strategically position British troops. Higher elevations possessed a more European climate, which led to the development of "hill stations" to protect and restore the health of soldiers. Relocating troops to hill stations would create a more fit and resilient infantry. Naturally, the Army could not afford to remove all British troops from the plains to the hills for health reasons. Staff Surgeon-General Dr. Ludovick C. Steward [15] (p. 320) contended,

Political reasons, I believe, are against the plan of stationing any very large proportion of our troops in the hills. They must be at hand, near the large cities, in terrorem; but I think every argument is in favour of having all the weakly men of these regiments, besides those actually diseased, sent periodically out of the plains. A season at such a place as Landour for a young soldier when he begins to droop, or feel very seedy, might, and most probably would, save his life, and the country, the expense of his voyage home as an invalid.

Dr. Steward's [15] (p. 329) suggestion to allow the troops a respite in the hills was opposed by others who argued that placing the troops in the hills year around would have not only a greater impact on the overall health of the troops, but would lead to serious effects on the psyche of the Indians:

One phase of the question, in a political sense, is comprehensible to those who have resided any time in India. It is said, that were the great majority of the European soldiers kept continuously in the hills and brought down to the plains occasionally in the cold weather, and massed in large bodies for drill, that the effect would be more influential on the native mind than the association of limited numbers in numerous and scattered cantonments in the plains. No people are more imaginative than the natives of India, they are often more impressed by narratives and traditions of what is removed from their constant observation than by daily association. It is a question if the habits of British soldiers tend to raise the European character in the estimation of the natives. It is a fact, at least, that those natives who have been brought up in their intimacy as servants and traders have not gained much by their acquired civilization.

The deployment and maneuvers of the Army were thus politically driven and complicated by the need to guard the health of troops while promoting the image of control.

\section{Discussion}

This section reflects upon the development of military water and sanitation initiatives as ideology and tactics, after which we briefly discuss its evolving relationships with civilian public health "beyond the barracks."

\subsection{Military Water and Sanitation as Ideology and Tactics}

Heightened anxieties about the health of the British troops led to improvements in cantonment water and sanitary conditions in India. The ideology of sanitary science and engineering emerged through colonial processes of control, coupled with western-oriented scientific methods of studying disease transmission. In Europe, scientific discoveries were transforming western knowledge about 
communicable diseases. The 1854 discovery of the transmission of cholera by contaminated drinking water, while much debated at the time in India, eventually brought about a dramatic rethinking of theories of contagious disease [61-65]. In the British colonies, hypotheses about purity, pollution, and disease transmission combined with a new health surveillance ideology to underscore the mission of improving the health of the troops. As David Gilmartin [27] (p. 1127) has argued, "the advance of science and advance of colonial rule went hand in hand. Science helped to secure colonial rule, to justify European domination over other peoples, and to transform production for an expanding world economy."

During the period of concern here, the field of sanitary medicine led to laws and regulations for improved sanitation. Implementation of these norms was increasingly carried out by the knowledge and skills of professional engineers, doctors, and civil servants. Army Medical Department Sanitary Reports attest to the importance of jointly scientific, cultural and practical debates about cantonment layout and design. The AMD [15] (p. 313) recognized these tensions when stating that,

... principles which should govern a military cantonment, and the antagonism inseparable from the clashing of strategic and hygienic considerations. The arrangements, for example, which enable the smallest number of men to defend a place against attack, are incompatible with that segregation of the force which is desirable on sanitary grounds. In drainage also, the conflicting views of eastern and western sanitarians have contributed to retard the adoption of efficient measures; and till the principles upon which the drainage of inter-tropical stations should be affected, have been settled, and the mode of scavenging finally determined on, this must necessarily be the case.

Harrison [66] (p. 30) has underscored the importance of drinking water supply, "Pure water was generally considered by sanitary officers in India to be the keystone of sanitary reform. An awareness of the issue was apparent even in the 1850s, but official interest was largely confined to the purity of water supplies in European settlements and military cantonments. But by the 1890s, sanitary officers had begun to consider the effects of impure water on the health of the population in general; their demands had become more frequent and their tone more strident." The period between the 1850s and 1890s involved a major struggle over the scientific basis of waterborne disease. While sanitarians' primary attention was directed toward European enclaves, by the 1880s, "The awakening of interest in rural health seems to have stemmed ... also from a growing awareness among British officials (particularly sanitary officers) that high levels of disease among the Indian population constituted a serious drain upon imperial productivity" [66] (p. 33).

\subsection{Beyond the Barracks: Representation and Voice}

The Sanitary Reports provided detailed accounts of imperial concerns regarding the health of British soldiers and their extended social network of European civilians, native troops, and wider society. Disease from the British military perspective was based on selected information that largely neglected experiences and perceptions of health and disease among most Indian social groups during the mid-19th century. Even within the military perspective, little was revealed about the soldiers themselves, what their attitudes were towards water, sanitation, and disease; and what the impacts of illness were on their lives, including their increasingly familial lives, their views of Indians, and their feelings about being posted in an unfamiliar and distant land. These voids seem minor, however, in comparison with the obscuring of day-to-day Indian life that took place just beyond the army barracks. Driven by racial prejudices and colonial biases, the AMD Sanitary Reports objectified Indians and their spaces and neglected or silenced their experience with and responses to the diseases and ill-health transmitted by British troops.

Representing, but not giving voice to, the attitudes of indigenous people, the Sanitary Reports leave us with a very incomplete view of health in mid-19th century India. Indians were purportedly ignorant of and indifferent to sanitation, hygiene, and environmental health in their bazaars, villages, and 
pilgrimage sites. Sanitary Reports asserted that the native population simply did not have a "sanitary mentality." Recent histories of traditional Indian health and medicine refute those presumptions [30,31]. Indian women in particular were objectified as a source of sickness and impurity that tainted the moral and physical character of the soldiers. In the Sanitary Reports, disease impacted mainly the British troops, which necessitated mechanisms for exerting social control over Indian people and places. Even the language employed in Sanitary Reports perpetuated dominance and dependence. Dossal [67] (p. 4) notes that the term "native" was part of "a linguistic process which denied the uniqueness of the one and elevated the other."

At the same time, we found that the reports had complex representations of "native" population groups, including some, and excluding others, from military spaces and purview. These categories and relations varied over time and space, as cantonments evolved from barracks to elite family enclaves, up to the present day. These enclaves have tried to regulate adjacent bazaars and upstream village wastewater discharge, in some cases using arbitrary distances of five to ten miles beyond the cantonment boundaries, with limited effectiveness.

Cantonment authorities and Army sanitarians interacted with yet remained separated from municipal officers and presidency sanitarians. In her study of female infanticide and colonial policy in India, Satadru Sen [68] (p. 54-55) points out that, "during the second half of the 19th century, the colonial state insisted upon its right to observe." The Contagious Disease Act of 1868 which emphasized venereal disease was part of a wider colonial project of reform grew out of a, " . . perception that the Mutiny had germinated in the secret recesses of native society" [68] (p. 55), [69,70]. And what about the experiences of those who were unheard and misrepresented? What was the subaltern Indian experience with disease and health care during the 1860s? What were the local medical systems which were called upon in times of distress and disease outbreaks (e.g., the Greco-Islamic tradition of unani tibb, the ancient Hindu ayurvedic tradition, etc.) [30,31]? What were the Indian reactions to military sanitary reform? To what extent was the western system of sanitation and medicine adopted or blended with traditional Indian systems? And what was the role of Indian elites in constructing policies and health measures at municipal and district levels that in some cases further exacerbated selective and degrading sanitary interventions in Indian communities? The answers to these questions appear to be more complex than has been represented in Sanitary Reports or in modern critical discourse. Research on public Sanitation Commissions and their reports offer important insights that may be pursued, along with the rich Hindi and Urdu literatures on indigenous medical systems that operated, sometimes in competition and at other times in combination with western medicine from the mid-19th century onwards $[4,29,39]$. Military sanitation was by no means hermetically separated from these parallel practices, but the Sanitary Reports gave them limited attention.

\section{Conclusions}

The early Army Medical Department's Sanitary Reports did not address the full range of issues raised by the 1859 Royal Commission Report or Florence Nightingale's Observations in 1863 [42]. Nightingale began like her colleagues on the Commission with a core concern for British troops and their imperial mission. Over the course of four decades, however, she progressively widened her advocacy for liberalizing policies of rural health, women's health, female nursing, peasant tenant's rights, and ultimately political rights-all of which she regarded as contributing to the wider "health" of India and Britain - as did many public health advocates and organizations of her era. In a detailed biographical assessment of Nightingale's efforts, however, Jharna Gourlay [45] (p. 271) concludes that Nightingale was ultimately, "depressed about her Indian work and its lack of overt success" beyond the sphere of military hygiene.

In this study, we show that relations between military and civilian water and sanitation have always been partially separate and partially connected with one another in India. Partially enclaved, and partially networked. Even enclaved cantonments have been connected in myriad ways with nearby bazaars, villages, towns, rivers, and so on. At the same time, military spaces have had privileged water 
access and sanitation services that have evolved in relation to changing ideas and tactics related to the waterborne etiology of cholera and other infectious diseases.

Gender dynamics likewise have changed from the heavy emphasis on male soldiers in the mid-19th century, to the increasingly domesticated cantonments of the early 21st century. They remain fundamentally important to water and sanitary improvements and inequalities "beyond the barracks" $[25,26]$. Today one reads, "The Cantonments, despite having financial and land constraints especially towards their permissible use for residential and commercial activities, today represent the green areas which strive to maintain ecological balance while at the same time providing better civic facilities to the residents" [39].

The legacy of mid-19th century military sanitation is profound. All but six of the 62 cantonments administered by the Directorate General of Defense Estates in India in 2019 were created prior to independence in 1947, and many of them before 1857. Following independence, other defense establishments such as defense colonies and housing authorities, have expanded dramatically. In 1992, there was an unsuccessful attempt in India to transfer control over cantonments to municipalities, in part to develop their "excess lands." In Delhi, the elite residential Defence Colony has witnessed new real estate development atop a contaminated nallah (channel) that flows alongside it. In Pakistan, the Defence Housing Authorities (DHA) are some of the country's largest urban landowners and developers. In many cases, these properties retain their own water and sanitation systems and they continue to feel the tensions between internal environmental control and upstream sources (and downstream discharge) of pollution. The entrenched legacy of military establishments in cities across South Asia has thus continued to produce variegated water and sanitation services and privileges, from the East India Company to the present day.

Author Contributions: S.J.H. and J.L.W.J. contributed jointly to conceptualization, methodology, analysis, writing and editing. All authors have read and agreed to the published version of the manuscript.

Funding: This research received no external funding.

Acknowledgments: A very early version of this paper was presented at the 'Gender-Water Geographies' session of meeting of the Association of American Geographers organized by Kathleen O'Reilly. We would like to thank Richa Nagar for her helpful comments on that earlier draft. We appreciate the cartographic support provided by Kevin McManigal and Miles Scheuering.

Conflicts of Interest: The authors declare no conflict of interest.

\section{References}

1. Chaplin, S. Politics of Sanitation in India: Cities, Services and the State; Orient Blackswan: New Delhi, India, 2011.

2. Kaye, J.; Malleson, G.B. History of the Indian Mutiny of 1857-8 (6 Volumes); Longmans, Green \& Co.: London, UK, 1909.

3. Metcalf, T. Aftermath of Revolt: Lndia 1857-1870; Princeton University Press: Princeton, NJ, USA, 1964.

4. Cowell, C. The Kacchā-Pakkā Divide: Material, Space and Architecture in the Military Cantonments of British India (1765-1889). ABE J. 2016, 9-10. Available online: http://journals.openedition.org/abe/3224 (accessed on 12 April 2019). [CrossRef]

5. Harrison, M. Public Health in British India: Anglo-Indian Preventive Medicine, 1859-1914; Cambridge University Press: New York, NY, USA; London, UK, 1994.

6. Nightingale, F. Florence Nightingale on Health in India: Collected Works of Florence Nightingale; Vallée, G., Ed.; Wilfrid Laurier University: Waterloo, ON, Canada, 2006; Volume 9.

7. Nightingale, F. Florence Nightingale on Social Change in India; Lynn McDonald, L., Vallée, G., Eds.; Wilfrid Laurier University: Waterloo, ON, Canada, 2007; Volume 10.

8. Burton, A. Burdens of History: British Feminists, Indian Women and Imperial Culture, 1865-1915; University of North Carolina Press: Chapel Hill, NC, USA, 1994.

9. Mukherjee, S. Gender, Medicine, and Society in Colonial India. Women's Health Care in Nineteenth and Early Twentieth-Century Bengal; Oxford University Press: New Delhi, India, 2017. 
10. Arnold, D. Colonizing the Body: State Medicine and Epidemic Disease in Nineteenth-Century India; University of California Press: Berkeley, CA, USA, 1993.

11. Biswamoy, P.; Harrison, M. The Social History of Health and Medicine in Colonial India; Routledge: New Delhi, India, 2009.

12. Army Medical Department (AMD). Statistical, Sanitary, and Medical Reports for the Year 1859; Harrison \& Sons, for Her Majesty's Stationery Office: London, UK, 1861.

13. Army Medical Department (AMD). Statistical, Sanitary, and Medical Reports for the Year 1860; Harrison \& Sons, for Her Majesty's Stationery Office: London, UK, 1862.

14. Army Medical Department (AMD). Statistical, Sanitary, and Medical Reports for the Year 1861; Harrison \& Sons, for Her Majesty's Stationery Office: London, UK, 1863.

15. Army Medical Department (AMD). Statistical, Sanitary, and Medical Reports for the Year 1862; Harrison \& Sons, for Her Majesty's Stationery Office: London, UK, 1864.

16. Army Medical Department (AMD). Statistical, Sanitary, and Medical Reports for the Year 1863; Harrison \& Sons, for Her Majesty's Stationery Office: London, UK, 1865.

17. Army Medical Department (AMD). Statistical, Sanitary and Medical Reports for the Year 1864; Harrison \& Sons, for Her Majesty's Stationery Office: London, UK, 1866.

18. Army Medical Department (AMD). Statistical, Sanitary, and Medical Reports for the Year 1865; Harrison \& Sons, for Her Majesty's Stationery Office: London, UK, 1867.

19. Army Medical Department (AMD). Statistical, Sanitary, and Medical Reports for the Year 1866; Harrison \& Sons, for Her Majesty's Stationery Office: London, UK, 1868.

20. Army Medical Department (AMD). Statistical, Sanitary, and Medical Reports for the Year 1867; Harrison \& Sons, for Her Majesty's Stationery Office: London, UK, 1869.

21. Army Medical Department (AMD). Statistical, Sanitary, and Medical Reports for the Year 1868; Harrison \& Sons, for Her Majesty's Stationery Office: London, UK, 1870.

22. Army Medical Department (AMD). Statistical, Sanitary, and Medical Reports for the Year 1869; Harrison \& Sons, for Her Majesty's Stationery Office: London, UK, 1871.

23. Kalal, D.D. Pune Cantonments Population: An Analysis of its Socio-Economic Dimension Using Factorial Ecology Approach; unpublished dissertation; Savitribai Phule Pune University, Department of Geography: Pune, India, 1999.

24. Kulkarni, K.M. Cantonment Towns of India. Ekistics 1979, 44, 214-220.

25. Birkenholtz, T. Dispossessing Irrigators: Water Grabbing, Supply-side Growth and Farmer Resistance in India. Geoforum 2016, 69, 94-105. [CrossRef]

26. Kulkarni, S.; O'Reilly, K.; Bhat, S. No Relief: Lived Experiences of Inadequate Sanitation Access of Poor Urban Women in India. Gend. Dev. 2017, 25, 167-183. [CrossRef]

27. O'Reilly, K.; Dhanju, R. Hybrid Drinking Water Governance: Community Participation and Ongoing Neoliberal Reforms in Rural Rajasthan, India. Geoforum 2012, 43, 623-633. [CrossRef]

28. Gilmartin, D. Scientific Empire and Imperial Science: Colonialism and Irrigation Technology in the Indus Basin. J. Asian Stud. 1994, 53, 1127-1149. [CrossRef]

29. Kumar, D. Disease and Medicine in India: A Historical Overview; Indian History Congress: New Delhi, India, 2001.

30. Sigerist, H.E. A History of Medicine: Volume 2: Early Greek, Hindu, and Persian Medicine; Oxford University Press: Oxford, UK, 1961.

31. Alavi, S. Islam and Healing: Loss and Recovery of an Indo-Muslim Tradition, 1600-1900; Palgrave: London, UK, 2008.

32. Sivaramakrishnan, K. Old Potions, New Bottles: Recasting Indigenous Medicine in Colonial Punjab, 1850-1945; Orient Longmans: New Delhi, India, 2006.

33. Hegewald, J.B. Water Architecture in South Asia: A Study of Types, Developments and Meanings; E.J. Brill: Leiden, The Netherlands, 2002.

34. Saini, A. Physicians of Colonial India (1757-1900). J. Family Med. Prim. Care 2016, 5, 528-532. [CrossRef]

35. Cornwallis, M. General Regulations and Orders Relative to the Duties in the Field and in Cantonments, Issued by the Marquis Cornwallis; George Grierson, Printer to the King's Most Excellent Majesty: Dublin, UK, 1798.

36. Pelling, M. Cholera, Fever and English Medicine, 1825-1865; Oxford University Press: Oxford, UK, 1978. 
37. Harrison, M. Differences of Degree: Representations of India in British Medical Topography, 1820-1870. Med. Hist. 2000, 20, 51-69.

38. Jepson, W. Of Soil, Situation, and Salubrity: Medical Topography and Medical Officers in Early Nineteenth-Century British India. J. Hist. Geogr. 2004, 32, 137-155.

39. Medical Board Office. Report on the Medical Topography and Statistics of the Northern, Hyderabad and Nagpore Divisions, the Tenasserim Provinces, and the Eastern Settlements; R.W. Thorpe: Madras, India, 1844.

40. Directorate General Defence Estates (DGDE) Historical Perspective. Ministry of Defence, Government of India, 2019. Available online: https://www.dgde.gov.in/content/historical-perspective (accessed on 22 December 2019).

41. Hume, J.C., Jr. Colonialism and Sanitary Medicine: The Development of Preventive Health Policy in the Punjab, 1860-1900. Mod. Asian Stud. 1986, 20, 703-724. [CrossRef]

42. Tuson, P. Mutiny Narratives and the Imperial Feminine: European Women's Accounts of the Rebellion in India in 1857. Women's Stud. Int. Forum. 1998, 21, 291-303. [CrossRef]

43. Nightingale, F. Observations on the Evidence Contained in the Stational Reports Submitted to Her by the Royal Commission on the Sanitary State of the Army in India; Edward Stanford: London, UK, 1863.

44. Lal, M. The politics of gender and medicine in colonial India: The Countess of Dufferin's Fund, 1885-1888. Bull. Hist. Med. 1994, 68, 29-66. [PubMed]

45. Gourlay, J. Florence Nightingale and the Health of the Raj; Ashgate Publishing Co.: Burlington, VT, USA, 2003.

46. Government of India. Act XXII of 1864, Regulations for the Administration of Civil and Criminal Justice in Cantonments, As Well As Sanitary Controls; Government of India: Calcutta, India, 1864.

47. Sanitary Commission. Report on Measures Adopted for Sanitary Improvements in India: From June 1869 to June 1870; Together with Abstracts of Sanitary Reports for 1868 Forwarded from Bengal, Madras, and Bombay; Her Majesty's Stationery Office: London, UK, 1870.

48. Sanitary Commission for Bombay. Report of the Sanitary Commission for Bombay, 1864; The Secretary to Government: Bombay, India, 1865.

49. Sanitary Commission for Bombay. In Proceedings of the Sanitary Commissioner, 1865-1873; Board of Public Health Works: Bombay, India, 1873; Available online: https://play.google.com/books/reader?id= WJAIAAAAQAAJ\&hl=en\&pg=GBS.PA29 (accessed on 12 April 2019).

50. Guha, S. Nutrition, Sanitation, Hygiene, and the Likelihood of Death: The British Army in India c. 1870-1920. Popul. Stud. 1993, 47, 385-401. [CrossRef] [PubMed]

51. Duffy, J. The Sanitarians: A History of Public Health; University of Illinois Press: Urbana, IN, USA, 1990.

52. Bynum, W.F. An Experiment that Failed: Malaria Control at Mian Mir. Parassitologia 1994, 36, 107-120.

53. Kenny, J. Climate, Race, and Imperial Authority: The Symbolic Landscape of the British Hill Stations. Ann. Am. Assoc. Geogr. 1995, 85, 694-714. [CrossRef]

54. Sheikh, M. Public Health and Sanitation in Colonial Lahore, 1849-1910, unpublished dissertation; University of Waterloo: Waterloo, ON, Canada, 2018.

55. Arnold, D. Cholera and Colonialism in British India. Past Present. 1986, 113, 118-151. [CrossRef]

56. De Renzy, A.C.C. Remarks on the Report of the Sanitary Commissioner with the Government of India on the Cholera Epidemic of 1872 in Northern India; Superintendent of Government Printing: Lahore, India, 1874.

57. Naval and Military Services. Annals of Military and Naval Surgery and Tropical Medicine and Hygiene: An Annual Retrospect Embracing the Experience of the Medical Officers of Her Majesty's Armies and Fleets in All Parts of the World, Volume 1, for the Year 1863; John Churchill \& Sons: London, UK, 1864.

58. Legg, S. Spaces of Colonialism: Delhi's Urban Governmentalities; Blackwell Publishing Limited: Oxford, UK, 2007.

59. Legg, S. Governing Prostitution in Colonial Delhi: From Cantonment Regulations to International Hygiene (1864-1939). J. Soc. Hist. 2009, 34, 447-467. [CrossRef]

60. Davies, P. Troughs \& Drinking Fountains: Fountains of Life; Chatto \& Windus: London, UK, 1989.

61. Snow, J. On the Mode of Communication of Cholera, 2nd ed.; J. Churchill Publishers: London, UK, 1855.

62. Watts, S. Epidemics and History: Disease, Power and Imperialism; Yale University Press: London, UK, 1997.

63. Watts, S. From Rapid Change to Stasis: Official Responses to Cholera in British-Ruled India and Egypt: 1860 to c. 1921. J. World Hist. 2001, 12, 321-374. [CrossRef]

64. Wescoat, J.L., Jr. Water, works, and health in colonial Lahore, Pakistan, 1849-1869, Unpublished Paper Presented at the Institute of Behavioral Sciences; The University of Colorado at Boulder: Boulder, CO, USA, 1995.

65. Wescoat, J.L., Jr. Waterworks and Culture in Metropolitan Lahore. Asian Art Cult. 1995, 8, 21-36. 
66. Harrison, M. Towards a Sanitary Utopia? Professional Visions and Public Health in India, 1890-1914. South Asia Res. 1990, 10, 19-40. [CrossRef]

67. Dossal, M. Imperial Designs and Indian Realities: The Planning of Bombay City, 1845-1875; Oxford University Press: Bombay, India, 1991.

68. Sen, S. The Savage Family: Colonialism and Female Infanticide in Nineteenth-Century India. J. Women's Hist 2002, 14, 53-81. [CrossRef]

69. Wald, E. Health, Discipline and Appropriate Behaviour: The Body of the Soldier and Space of the Cantonment. Mod. Asian Stud. 2012, 46, 815-856. [CrossRef]

70. Wald, E. Vice in the Barracks: Medicine, the Military and the Making of Colonial India, 1780-1868; Palgrave Macmillian: London, UK; New York, NY, USA, 2014.

(C) 2020 by the authors. Licensee MDPI, Basel, Switzerland. This article is an open access article distributed under the terms and conditions of the Creative Commons Attribution (CC BY) license (http://creativecommons.org/licenses/by/4.0/). 